\title{
САМОРОДНЫЕ МЕТАЛЛЫ И ИХ ОКСИДЫ ИЗ ХРОМИТИТОВ КЕМПИРСАЙСКОГО УЛЬТРАМАФИТОВОГО МАССИВА (ЮЖНЫЙ УРАЛ, КАЗАХСТАН)
}

\section{Юричев А.Н., Карбовяк Е.В.}

Томский государственный университет, Томск, juratur@sibmail.com

Кемпирсайский массив является крупнейшим массивом ультрамафитов на юге Урала. Он входит в состав южноуральского ультрамафитового пояса, который является продолжением мафитультрамафитового платиноносного пояса среднего и северного Урала, и является составной частью крупного Сакмарского аллохтона, представляющего собой реликт океанической коры раннепалеозойского возраста, шарьированного на восточную окраину Восточно-Европейского палеоконтинента в средне-, верхнепалеозойское время $[2,11]$.

Массив и его гигантские по масштабам хромитовые месторождения были и являются предметом многочисленных фундаментальных исследований. Современные представления о возрасте, строении, составе массива и его оруденении базируются на работах В.П. Логинова, Н.В. Павлова, Г.А. Соколова, И.И. Григорьевой, Г.Г. Кравченко, Г.Н. Савельевой и др. [5, 7-8, 10].

При изучении вещественного состава хромшинелидов и акцессорных сульфидов в средне и густовкрапленных хромититах, отобранных в карьере «Объединенный» Алмаз-Жемчужного хромитового месторождения Кемпирсайского ультрамафитового массива (Казахстан), авторами были диагностированы единичные мелкие (до 0.04 мм) проявления самородных металлов и их оксидов: самородный никель, самородная медь, самородное железо, аваруит $\left(\mathrm{FeNi}_{3}\right)$, кассетерит $\left(\mathrm{SnO}_{2}\right)$, монтепанит (CdO), цинкит ( $\mathrm{ZnO})$ (рис. 1).

Самородный никель отмечается в виде одиночных округлых каплевидных выделений с корродированными краями в интерстициях зерен хромшпинелидов. Размеры таких выделений не превышаю 0.04 мм. В химическом составе минерала постоянно отмечается примесь $\mathrm{Fe}$ (до $11 \%$ и $\mathrm{Cu}$ (до $5 \%$ ) (табл. 1).

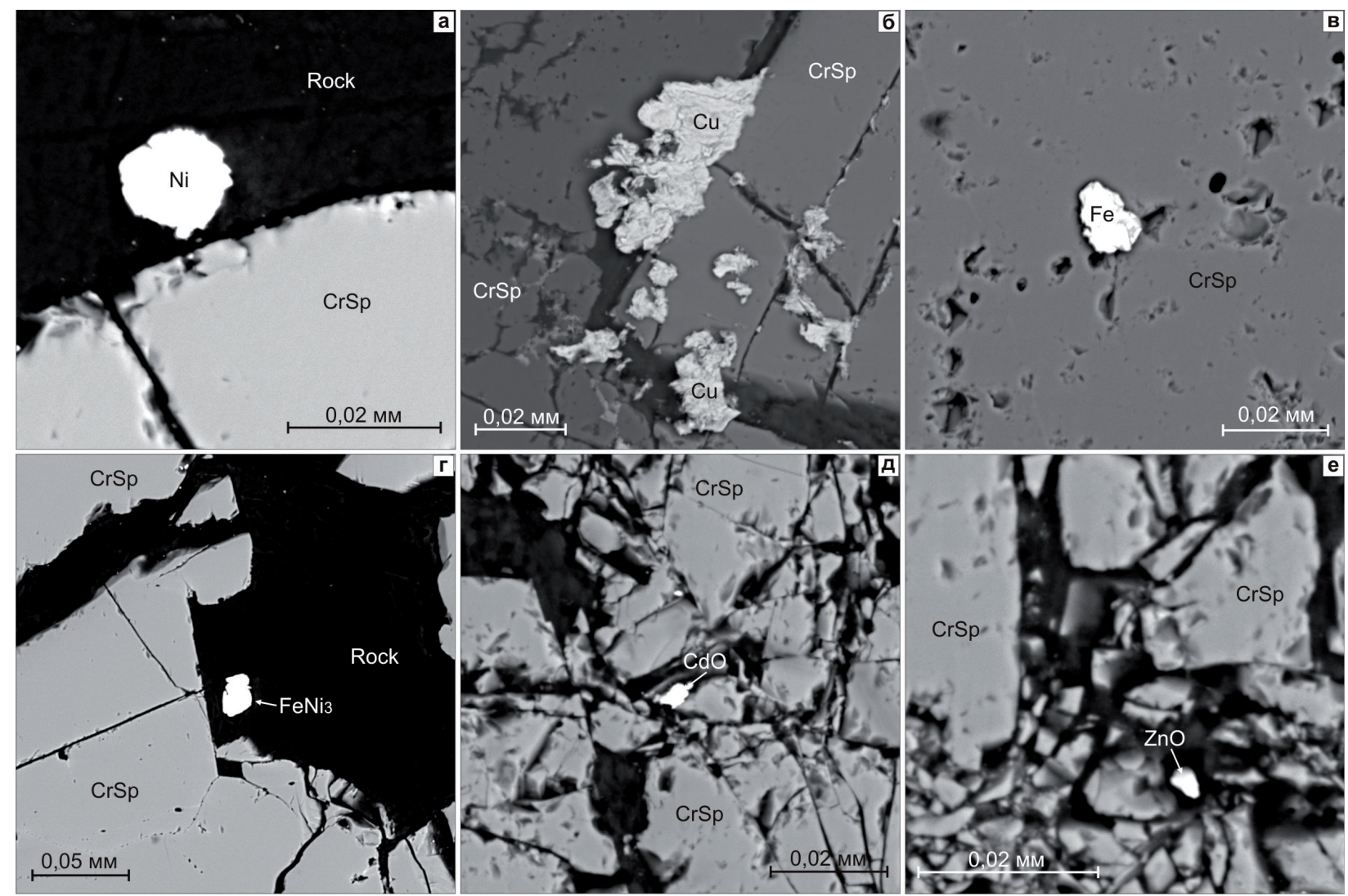

Рис. 1. Минерализация самородных металлов и их оксидов в хромититах Кемпирсайского ультрамафитового массива (снимки в режиме BSE). CrSp - хромшпинелид; Rock - хлорит-серпентинитовый агрегат. 
Самородные медь и железо формирует сгустковидные, неправильные или чешуйчатые (чаще) выделения размером до 0.03 мм непосредственно в зернах хромшпинелидов либо в интерстициях между ними (рис. 1, б-в). В химическом составе первого минерала постоянно отмечается примесь $\mathrm{Fe}$ (до $3.5 \%$ ), реже - Ni (до $1 \%$ ), а в составе второго - $\mathrm{Cr}$ (до $4.8 \%$ ) и $\mathrm{Mn}$ (до $0.5 \%$ ) (табл. 1).

Таблица 1. Химический состав самородных металлов и их оксидов в хромититах Кемпирсайского ультрамафитового массива, вес. \%.

\begin{tabular}{|c|c|c|c|c|c|c|c|c|c|c|c|}
\hline Минерал & Образец & $\mathrm{Ni}$ & $\mathrm{Cu}$ & $\mathrm{Fe}$ & $\mathrm{Mn}$ & $\mathrm{Zn}$ & $\mathrm{Sn}$ & $\mathrm{Cd}$ & $\mathrm{Cr}$ & $\mathrm{O}$ & Сумма \\
\hline \multirow{2}{*}{ Самородный никель } & 939/545-2.1 & 82.96 & 4.57 & 10.89 & - & - & - & - & - & - & 98.42 \\
\hline & $939 / 545-2.4$ & 83.67 & 4.83 & 10.86 & - & - & - & - & - & - & 99.36 \\
\hline \multirow{2}{*}{ Самородная медь } & KM 947/55-2.1 & 1.00 & 94.30 & 3.36 & - & - & - & - & - & - & 98.66 \\
\hline & $3 / 1-21.1$ & - & 98.67 & 0.45 & - & - & - & - & - & - & 99.12 \\
\hline Самородное железо & э-4/1 & - & - & 94.66 & 0.55 & - & - & - & 4.80 & - & 100.01 \\
\hline \multirow{4}{*}{ Аваруит } & $939 / 545-5.1$ & 73.42 & - & 24.74 & - & - & - & - & 1.63 & - & 99.79 \\
\hline & $939 / 545-5.2$ & 74.35 & - & 24.17 & - & - & - & - & 1.39 & - & 99.90 \\
\hline & $939 / 545-7.1$ & 74.88 & - & 23.69 & - & - & - & - & 1.43 & - & 100.00 \\
\hline & $939 / 545-7.2$ & 74.86 & - & 23.53 & - & - & - & - & 1.61 & - & 100.00 \\
\hline \multirow{2}{*}{ Кассетерит } & $3 / 1-1.1$ & - & - & - & - & - & 74.71 & - & - & 25.12 & 99.83 \\
\hline & $3 / 1-1.2$ & - & - & - & - & - & 75.82 & - & - & 23.96 & 99.78 \\
\hline Монтепонит & $3 / 1-22.1$ & - & - & - & - & - & - & 86.16 & - & 13.85 & 100.01 \\
\hline Цинкит & $3 / 1-24.2$ & - & - & - & - & 80.00 & - & - & - & 19.55 & 99.55 \\
\hline
\end{tabular}

Примечание. Анализы выполнены на электронном сканирующем микроскопе «Tescan Vega II LMU», оборудованном энергодисперсионным спектрометром (с детектором $\mathrm{Si}(\mathrm{Li}) \mathrm{Standard}$ ) INCA Energy 350 и волнодисперсионным спектрометром INCA Wave 700 в ЦКП «Аналитический центр геохимии природных систем» ТГУ (г. Томск), оператор Е.В. Карбовяк. Для исследования использованы образцы хромититов из личной коллекции профессора Томского государственного университета Чернышова А.И.

$\mathrm{B}$ качестве металлического твердого раствора $\mathrm{Fe}$ и $\mathrm{Ni}$ в интерстициях хромшпинелидов диагностированы нередкие округлые и неправильные проявления аваруита, размером до 0.04 мм (рис. 1, г). Химический состав выявленных аваруитов близок стехиометрическому, а также химическим составам данного минерала из ультрамафитового массива г. Солдатской (п-ов Камчатский мыс, Восточная Камчатка) [6] и океанических перидотитов Срединно-Океанического хребта (Атлантический океан) [1]. Однако отличается от последних постоянным присутствием в химическом составе $\mathrm{Cr}$ (до 1.7 \%), который, очевидно, входит в состав минерала, «загрязняя» его, в виде тонкодисперсной механической примеси (табл. 1).

Оксиды $\mathrm{Sn}, \mathrm{Cd}$ и $\mathrm{Zn}$ диагностированы в хромититах Кемпирсайского массива предположительно впервые (?). Они отмечены в виде редких мелких (до 0.005 мм) округлых или неправильных по форме обособлений, заполняющих пустотки и каверны внутри преимущественно трещиноватых, раздробленных зерен хромшпинелидов (рис. 1, д-е). Их химические составы характеризуются относительной «чистотой» (отсутствием примесей других компонентов) и несколько отклоняются от стехиометрических (табл. 1).

Концентрирование выявленной минерализации, очевидно, связано с ее мобилизацией в процессе серпентинизации и преобразовании первичных силикатов, прежде всего оливина, а также находящихся с ними в парагенезисе сульфидов и шпинелей при восстановительных условиях [3-4, 9]. Образование металлов авторы связывают с тенденцией $\mathrm{Ni}$ и подчиненного $\mathrm{Fe}$ высвобождаться из кремнекислородных связей первичного оливина, а $\mathrm{Cu}$ и $\mathrm{Zn}$ - из связей сульфидов и хромшпинелидов и переходить в форму свободных элементов. Очевидно, что наряду с восстановлением самородных металлов из первичных силикатов, сульфидов или хромшпинелидов, возможен привнос части элементов $(\mathrm{Cd}, \mathrm{Sn})$ самими серпентинизирующими растворами.

Последующая судьба данных металлов, очевидно, определялась их концентрированием совместно с иными компонентами, не участвующими в главном процессе кристаллизации, и последующем их отложении из высоконасыщенных надкритических флюидов. 


\section{Литература}

1. Базылев Б. А. Развитие аваруитсодержащей минеральной ассоциации в перидотитах из зоны разлома 1520' (Атлантический океан) как одно из проявлений океанического метаморфизма // Российский журнал наук о Земле. 2000. Т. 2. № 3-4. С. 279-293.

2. Дистлер В.В., Крячко В.В., Юдовская М.А. Условия образования оруденения платиновых металлов в хромитовых рудах Кемпирсайского рудного поля // Геология и геофизика. 2003. Т. 45. № 1. С. 44-74.

3. Жмодик С.М., Агафонов Л.В. Шэндит и другие минералы никеля из хромититов офиолитовой ассоциации юго-восточной части Восточного Саяна // Геология и геофизика. 2000. Т. 41. № 5. С. 712-721.

4. Леснов Ф.П. Петрология полигенных мафит-ультрамафитовых массивов Восточно-Сахалинской офиолитовой ассоциации. Новосибирск: Академическое изд-во «Гео», 2015. 240 с.

5. Логинов В.П., Павлов Н.В., Соколов Г.А. Хромитоносность Кемпирсайского массива на Южном Урале // Хромиты СССР. М.: Изд-во АН СССР. 1940. С. 5-199.

6. Новаков Р.М., Москалева С.В., Иванов В.В., Паламарь С.В. Пентландиты и аваруиты гипербазитового массива горы Солдатской (п-ов Камчатский мыс, Восточная Камчатка) // Вестник КРАУНЦ. Науки о земле. 2014. № 2. С. 137-146.

7. Павлов Н.В., Григорьева И.И. Месторождения хрома // Рудные месторождения СССР. М.: Наука, 1974. T. 1. C. $168-220$.

8. Павлов Н.В., Кравченко Г.Г., Чупрынина И.И. Хромиты в Кемпирсайском плутоне. М.: Наука, 1968. 197 с.

9. Рамдор П. О широко распространенном парагенезисе рудных минералов, возникающих при серпентинизации (с некоторыми данными по новым и недостаточно изученным минералам) // Геология рудных месторождений. 1967. № 2. С. 32-43.

10. Савельева Г.Н., Савельев А.А. Офиолиты Кемпирсайского массива: основные черты структурновещественной эволюции // Геотектоника. 1991. № 6. С. 57-75.

11. Melher F., Stumpfl E.F., Distler V.V. Chromite deposits of the Kempirsai massif, southern Urals, Kazakhstan // Inst. Mining Metall. 1994. V. 103. P. 107-120. 